\title{
Human Platelet Collagenase
}

\author{
Carolyn McI. Chesney, Elvin Harper, and Robert W. Colman \\ From the Hematology Research and Developmental Biology Laboratories, \\ Massachusetts General Hospital and the Departments of Medicine and \\ Biochemistry, Harvard Medical School, Boston, Massachusetts 02115
}

\begin{abstract}
A B S TRACT The presence of proteolytic enzymes such as cathepsin and elastase in platelets and the important role of collagen in platelet aggregation suggested that collagenase might be present in platelets. Epinephrine, ADP, and collagen liberate collagenase from platelets in plasma as measured by the hydrolysis of $\left[{ }^{14} \mathrm{C}\right]$ glycine-labeled collagen fibrils. The collagenase activity appeared in an early phase of platelet aggregation and was not a part of the release reaction. However, only $50 \%$ of the total collagenase could be liberated by the aggregating agents used. Sucrose density gradient analysis of platelet homogenates using appropriate subcellular markers indicated that collagenase appeared in both the granule and membrane fractions. Gel-filtered platelets failed to show collagenase activity before exposure to aggregating agents but released more collagenolytic activity than was found in platelet-rich plasma. This observation was explained by the finding that collagenolytic activity was inhibited by normal human plasma. One of the inhibitors is $\alpha_{1}$-antitrypsin as demonstrated by decreased inhibition in plasma from a patient with homozygous $\alpha_{1}$-antitrypsin deficiency. Platelet collagenase activity could also be demonstrated by its ability to decrease the viscosity of collagen solutions and to produce collagen fragments similar to those produced by other mammalian collagenases on disk gel electrophoresis. The observation that partially purified platelet collagenase could destroy the platelet-aggregating activity of collagen suggests that the enzyme
\end{abstract}

This work was presented at the annual meeting of the American Society of Hematology, December, 1972.

Dr. Harper's present address is the Department of Chemistry, University of California at San Diego, La Jolla, Calif. Dr. Colman's present address is the Coagulation Unit of the Hematology-Oncology Section, Hospital of the University of Pennsylvania, Philadelphia, Pa. 19104.

Drs. Colman and Harper are recipients of National Institutes of Health Career Development Awards (HL-48075 and AM-15367) and Dr. Chesney is the recipient of an NIH Special Fellowship (HL-48190).

Received for publication 12 September 1973 and in revised form 30 January 1974. might function in a negative feedback mechanism limiting thrombus formation.

\section{INTRODUCTION}

Collagenases have been demonstrated in explants and culture fluids from a number of amphibian and mammalian tissues by their lytic action on native collagen substrates at neutral $\mathrm{pH}$ (1). These enzymes have been isolated and partially purified and their mode of attack on native collagen described (2). They hydrolyze native collagen at temperatures below the substrate denaturation temperature and give rise to characteristic reaction products at $27^{\circ} \mathrm{C}$.

Platelets have been shown to contain proteases including cathepsins and elastase (3). Since collagen plays an important role in platelet aggregation $(4,5)$, it was of interest to seek a collagenase associated with platelets. This study documents the presence of collagenolytic activity in platelets, investigates the relation of this enzyme to the platelet release reaction, and explores its subcellular localization.

\section{METHODS}

Platelet preparation -

Platelet-rich plasma $(P R P) .^{1}$ Human blood from normal volunteers was collected into an anticoagulant solution (1 part $3.8 \%$ sodium citrate to 9 parts whole blood) and centrifuged at $23^{\circ} \mathrm{C}$ for $10 \mathrm{~min}$ at $50 \mathrm{~g}$. Supernatant PRP was then removed by aspiration and used for the studies. Whole blood and plasma were exposed only to plastic surfaces. The platelet count varied from 200,000 to 350,000 per $\mu 1$ during these studies.

Platelet-poor plasma. Blood was collected as was PRP (see above) and centrifuged at 2,500 $g$ for $10 \mathrm{~min}$. The platelet count was less than 40,000 platelets per $\mu 1$.

Washed platelets. Platelets were filtered through Sepharose $2 \mathrm{~B}$ by using a modification of the method of Tangen, Berman, and Marfey (6). $5 \mathrm{ml}$ of PRP was applied to the top of a $2.5 \times 4.5-\mathrm{cm}$ column previously equilibrated with calcium-free Tyrode's buffer, $\mathrm{pH}$ 7.4. Fractions con-

\footnotetext{
${ }^{1}$ Abbreviation used in this paper: PRP, platelet-rich plasma.
} 
taining washed platelets appearing at the void volume of the column were pooled and human lyophilized fibrinogen (Grade L, 95\% clottable, Kabi, Stockholm, Sweden) was added to give final concentrations of $6 \mathrm{mg} / \mathrm{ml}$. Before addition of aggregating agents, $\mathrm{CaCl}_{2}$ was added to give a final concentration of $1 \mathrm{mM}$.

\section{Platelet aggregation and release}

Platelet aggregometry. Platelet aggregation was carried out as previously described (7).

Platelet release. Platelet release studies were performed by stirring $0.5 \mathrm{ml}$ of $\mathrm{PRP}$ or washed platelets in plastic tubes, $12 \times 75 \mathrm{~mm}$, with a magnetic stirrer at $1,200 \mathrm{rpm}$ (the same speed as the aggregometer). The temperature was maintained at $37^{\circ} \mathrm{C}$. Samples were stirred for $15 \mathrm{~min}$.

$\left[{ }^{14} \mathrm{C}\right]$ serotonin release. $\left[{ }^{14} \mathrm{C}\right]$ serotonin $(83.3 \mu \mathrm{Ci} / \mathrm{mg}$, New England Nuclear, Boston, Mass.) release was measured by the method of Jerushalmy and Zucker (8).

$\beta$-Glucuronidase. $\beta$-Glucuronidase was assayed according to the method of Fishman, Springer, and Burnetti (9) with phenolphthalein glucuronate as substrate.

Acid phosphatase. Acid phosphatase was assayed by the method of Brandenberger and Hanson (10) with $o$-carboxyphenyl-phosphate as substrate.

5'-nucleotidase. 5'-nucleotidase was assayed by the method of Dixon and Purdom (11) by using a kit obtained from Sigma Chemical Co., St. Louis, Mo. in which enzyme activity is determined by measuring inorganic phosphorus formed.

Protein determination. Protein determination was performed by the method of Lowry, Rosebrough, Farr, and Randall (12).

\section{Reagents for platelet aggregation and release}

Acid-soluble guinea pig skin collagen was prepared by the method of Gross (13). ADP was a product of Sigma Chemical Co. L-epinephrine was obtained from Winthrop Laboratories, Evanston, Ill.

All other chemicals were of reagent grade.

Preparation of platelet pellet for enzymatic studies

After the release reaction was complete, the platelets were centrifuged for $2 \mathrm{~min}$ at $18,000 \mathrm{~g}$ at $4^{\circ} \mathrm{C}$; the supernate was analyzed separately. The centrifugation step was repeated and the pellet resuspended in a volume of Tyrode's buffer equivalent to that of the supernate. The resuspended washed pellets were frozen and thawed six times in a dry ice-acetone mixture.

\section{Collagenase assays}

Polyacrylamide disk electrophoresis. A qualitative estimate of proteolysis was obtained by analysis of collagen reaction products $(80-160 \mu \mathrm{g})$ by polyacrylamide disk electrophoresis at $\mathrm{pH} 3.8$ using the method of Nagai, Gross, and Piez (14).

Viscometric assay. Collagenase was detected by measuring the decrease in viscosity at $27^{\circ} \mathrm{C}$ of an undenatured solution of guinea pig skin collagen (15).

Radiochemical assay. Collagenolytic activity was measured by the release of $\left[{ }^{14} \mathrm{C}\right]$ glycine degradation products from isotopically labeled guinea pig skin collagen fibrils (16). The assays were conducted at $37^{\circ} \mathrm{C}$ for $4 \mathrm{~h}$ with $0.4 \mathrm{ml}$ supernate and platelet pellet incubated with collagen fibrils as described (16). Linearity was confirmed by measurements at constant time for varying enzyme concentration and constant enzyme concentration for various types. A trypsin blank was included in each experiment to correct for any denatured collagen that might be susceptible to nonspecific proteases and cpm corrected by subtraction.

\section{Density gradient preparation of platelets}

Human platelets from random donors, which had been stored at $4^{\circ} \mathrm{C}$ for less than $72 \mathrm{~h}$, were obtained from the Massachusetts General Hospital Blood Bank. Examination of Wright's stained smear of these platelets revealed less than one white blood cell and five red cells per $2 \times 10^{4}$ platelets. Culture of this preparation on blood agar and McConkey media revealed no bacterial colonies after $24 \mathrm{~h}$ at $37^{\circ} \mathrm{C}$. Platelets were pooled and centrifuged for $30 \mathrm{~min}$ at $4^{\circ} \mathrm{C}$ at $2,000 \mathrm{~g}$. Platelet buttons were then washed in $0.05 \mathrm{M}$ Tris, $0.15 \mathrm{M} \mathrm{NaCl}, \mathrm{pH} 7.4$, and centrifuged. The procedure was repeated twice. These platelets were then prepared for sucrose gradient ultracentrifugation by a modification of the method of Marcus, Zucker-Franklin, Safier, and Ullman (17). In study $A$, the gradient of sucrose was stepwise, increasing from 30 to $60 \%$ by increments of $5 \%$. In study $\mathrm{B}$, the gradient was continuous and linear $(30-60 \%)$. In study $A$, an aliquot of platelets was labeled with $\left[{ }^{14} \mathrm{C}\right]$ serotonin before washing with the buffer and centrifuged simultaneously on a duplicate gradient.

\section{Partial purification of platelet collagenase}

$46 \mathrm{ml}$ of homogenized platelets prepared as described above were distributed in four 125-ml Erlenmeyer flasks, frozen in dry ice-acetone, and thawed in cold water. The resulting mixture was pooled and centrifuged for $30 \mathrm{~min}$ at $0^{\circ} \mathrm{C}$ at $27,000 \mathrm{~g}$. Solid $\left(\mathrm{NH}_{4}\right)_{2} \mathrm{SO}_{4}$ was added to the supernate at ice bath temperature to a final concentration of $30 \%$. The mixture was stirred for $1 \mathrm{~h}$, left in the ice bath for $30 \mathrm{~min}$, and then centrifuged as before. Both supernate and precipitate were dialyzed overnight versus $0.01 \mathrm{M}$ Tris chloride, $\mathrm{pH} 7.4$, containing $0.001 \mathrm{M} \mathrm{CaCl}$ at $4^{\circ} \mathrm{C}$. The supernate was then brought to $50 \%$ saturation by the gradual addition of solid $\left(\mathrm{NH}_{4}\right)_{2} \mathrm{SO}_{4}$. After centrifugation as previously performed, the precipitate was taken up in $0.05 \mathrm{M}$ Tris $\mathrm{HCl}, \mathrm{pH} \mathrm{7.4}$, containing $0.005 \mathrm{M} \mathrm{CaCl}_{2}$ and dialyzed versus the same buffer at $4^{\circ} \mathrm{C}$ overnight.

\section{RESULTS}

Studies in PRP. The platelet release reaction was studied in PRP (Table I). Low concentrations of ADP $(1 \mu \mathrm{M})$ produced reversible aggregation and no release of $\left[{ }^{14} \mathrm{C}\right]$ serotonin with the appearance of a small but significant amount of collagenase. Concentrations of ADP of 5 and $10 \mu \mathrm{M}$, which produced a second wave of aggregation, released $\left[{ }^{14} \mathrm{C}\right]$ serotonin and liberated increased collagenase activity. A lysosomal granule marker, $\beta$-glucuronidase (18) was not released. Platelets stirred in plasma, to which no aggregating agent was added, did not aggregate or release any of the platelet components measured and did not show any collagenase activity.

Studies on gel-filtered platelets. The platelet release reaction was studied in platelets rendered free of plasma proteins by gel filtration (Table II). As has been previ- 
TABLE I

Release from $P R P$

\begin{tabular}{lcccc}
\hline \multicolumn{1}{c}{ Agent } & Collagenase & Serotonin & $\beta$-Glucuronidase & $\begin{array}{c}\text { Platelet } \\
\text { aggregation }\end{array}$ \\
\hline Control & $c p m / m l^{*}$ & $\%$ released & $\mu m o l / m g / m i n$ & $\%$ normal \\
ADP $(1 \mu \mathrm{M})$ & 0 & 0 & 0 & 0 \\
ADP $(5 \mu \mathrm{M})$ & 20 & 0 & 0 & 31.0 \\
ADP $(10 \mu \mathrm{M})$ & 150 & 44.8 & 0 & 91 \\
Collagen & 245 & 42.8 & 0 & 100 \\
& 295 & 62.6 & 0 & 100 \\
\hline
\end{tabular}

The supernate $(0.4 \mathrm{ml})$ after exposure to the aggregating agent or, in the case of control, to stirring was incubated with each substrate for the time specified in the Methods or references.

* Original count of undigested labeled collagen $=2,200 \mathrm{cpm}$.

ously noted, $\left[{ }^{14} \mathrm{C}\right]$ serotonin release by $A D P$ is not as complete in washed platelets as in PRP (19). However, the release reaction with collagen is similar in both systems. Collagenase activity, after exposure to ADP, was present in greater amounts than that observed in PRP when specimens of equal platelet counts were compared. However, collagenase release per $10^{8}$ platelets was about the same after exposure to collagen in both systems. Approximately equal amounts of collagenase activity were present in the supernate and in the platelet pellet. As observed in PRP, the collagenase activity appeared when there was only reversible aggregation. Epinephrine $(25 \mu \mathrm{M})$, which also produces reversible aggregation of gel-filtered platelets, was able to liberate $72 \%$ of collagenase activity released by $10 \mu \mathrm{M}$ ADP.

Density gradient localization of enzyme activity. In the discontinuous gradient (study A), visible bands of dense granules, light granules, and membranes were seen (Fig. 1). The peak activity of the corresponding markers of $\left[{ }^{14} \mathrm{C}\right]$ serotonin, $\beta$-glucuronidase, and acid phosphatase, respectively, confirms the localization of these subcellular constituents (Fig. 2). However, in the course of preparation the homogenization employed apparently results in a partial solubilization of some of the components. Platelet collagenase appears in both membrane and light granule fractions.

Confirmation of these findings was obtained by use of a continuous gradient technique (study B) (Table III). The distribution of collagenase in the granules, membranes, and soluble fraction of the platelet homogenates were compared to known marker enzymes, $\beta$-glucuronidase for granules and $5^{\prime}$-nucleotidase (20) for membranes. While $5^{\prime}$-nucleotidase is apparently tightly bound to membranes, $\beta$-glucuronidase in this preparation was found not only in the granules but also in the membrane and soluble fractions. The granule fraction contained $40 \%$ of the activity, an amount similar to that found by Marcus and associates (17), who found $38.6 \%$ in that fraction. In constrast, collagenase, while not entirely confined to membrane, exhibits its highest specific activity in that fraction. However, $61 \%$ is localized either in the granule or in the soluble fraction. The collagenase in the soluble fraction may be due to liberation from granules or membranes.

Effect of inhibitors on collagenase activity. Since collagenase activity released into plasma by ADP was

TABLE II

Release from Platelets in Tyrode's Buffer

\begin{tabular}{|c|c|c|c|c|c|}
\hline \multirow[b]{2}{*}{ Agent } & \multicolumn{2}{|c|}{ Collagenase } & \multirow[b]{2}{*}{ Serotonin } & \multirow[b]{2}{*}{ B-Glucuronidase } & \multirow{2}{*}{$\begin{array}{c}\text { Platelet } \\
\text { aggregation }\end{array}$} \\
\hline & Supernate & Pellet & & & \\
\hline & \multicolumn{2}{|c|}{ cpm ${ }^{\prime} 10^{8}$ platelets } & $\%$ released & $\mu \mathrm{mol} / \mathrm{min} / \mathrm{ml}$ & \% normal \\
\hline Control & 0 & 0 & 0 & 0 & 0 \\
\hline $\operatorname{ADP}(1 \mu \mathrm{M})$ & 174 & 152 & 0 & 0 & 21.5 \\
\hline $\operatorname{ADP}(10 \mu \mathrm{M})$ & 302 & 400 & 0 & 0 & 56.3 \\
\hline $\operatorname{ADP}(2 \mathrm{mM})$ & 368 & 425 & 17.9 & 0 & 50.0 \\
\hline Collagen & 211 & 266 & 83.0 & 0 & 56.3 \\
\hline
\end{tabular}

The supernate $(0.4 \mathrm{ml})$ or platelet pellet resuspended in $0.4 \mathrm{ml}$ Tyrodes' buffer was incubated with end substrate as described in Methods.

* Original count of undigested labelled collagen $=1,650 \mathrm{cpm}$. 


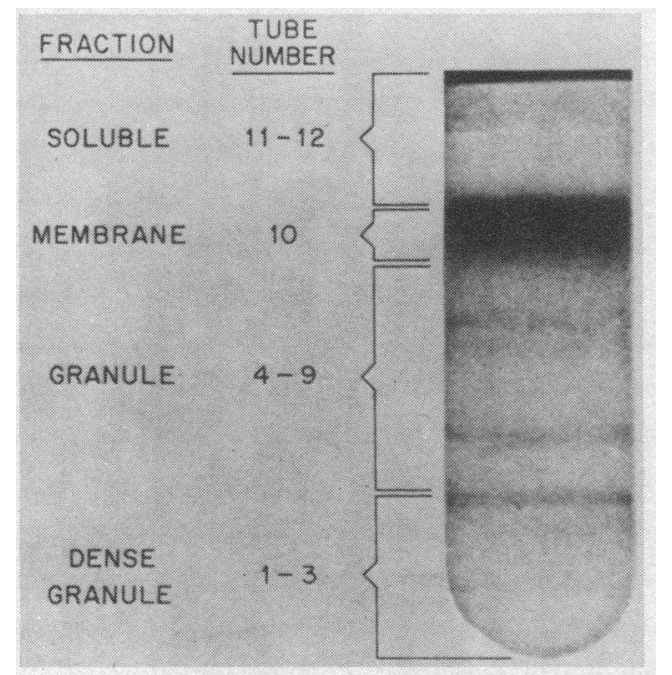

Figure 1 (Study A) Photograph of $5 \mathrm{ml}$ centrifuge tube showing the bands obtained from ultracentrifugation of $1.2 \mathrm{ml}$ of platelet homogenate.

consistently lower than that seen in washed systems, the effect of known human plasma inhibitors on the collagenase activity released by platelets was studied. In these experiments the supernate from washed platelets aggregated with $10 \mu \mathrm{M}$ ADP was used as a source of collagenase. Equal volumes of supernate and normal plasma were incubated together for $30 \mathrm{~min}$ at $37^{\circ} \mathrm{C}$. The collagenase was $97 \%$ inhibited as measured in the $\left[{ }^{14} \mathrm{C}\right]$ glycine peptide release assay. When $\alpha_{1}$-antitrypsindeficient plasma was substituted for the normal plasma under the same conditions, only $48 \%$ inhibition was observed.

$E D T A$. Washed platelets were incubated with $3 \mathrm{mM}$ EDTA before aggregation with $10 \mu \mathrm{M}$ ADP. No aggregation occurred and no collagenase activity was detected. To ascertain if this was due to prevention of aggregation or inhibition of the enzyme after liberation, the washed

TABLE III

Subcellular Distribution of Enzymes* (Study B)

\begin{tabular}{lccc}
\hline \multicolumn{1}{c}{ Enzyme } & Granules & Membranes & $\begin{array}{c}\text { Soluble } \\
\text { fraction }\end{array}$ \\
\hline Collagenase & $\%$ & $\%$ & $\%$ \\
$\beta$-Glucuronidase & 17 & 59 & 24 \\
5 '-Nucleotidase & 40 & 34 & 25 \\
& 0 & 100 & 0 \\
\hline
\end{tabular}

After sucrose density fractionation an aliquot of each fraction was incubated with each substrate as indicated in Methods.

* Results reported as a percentage of the sum of the recovered activities.
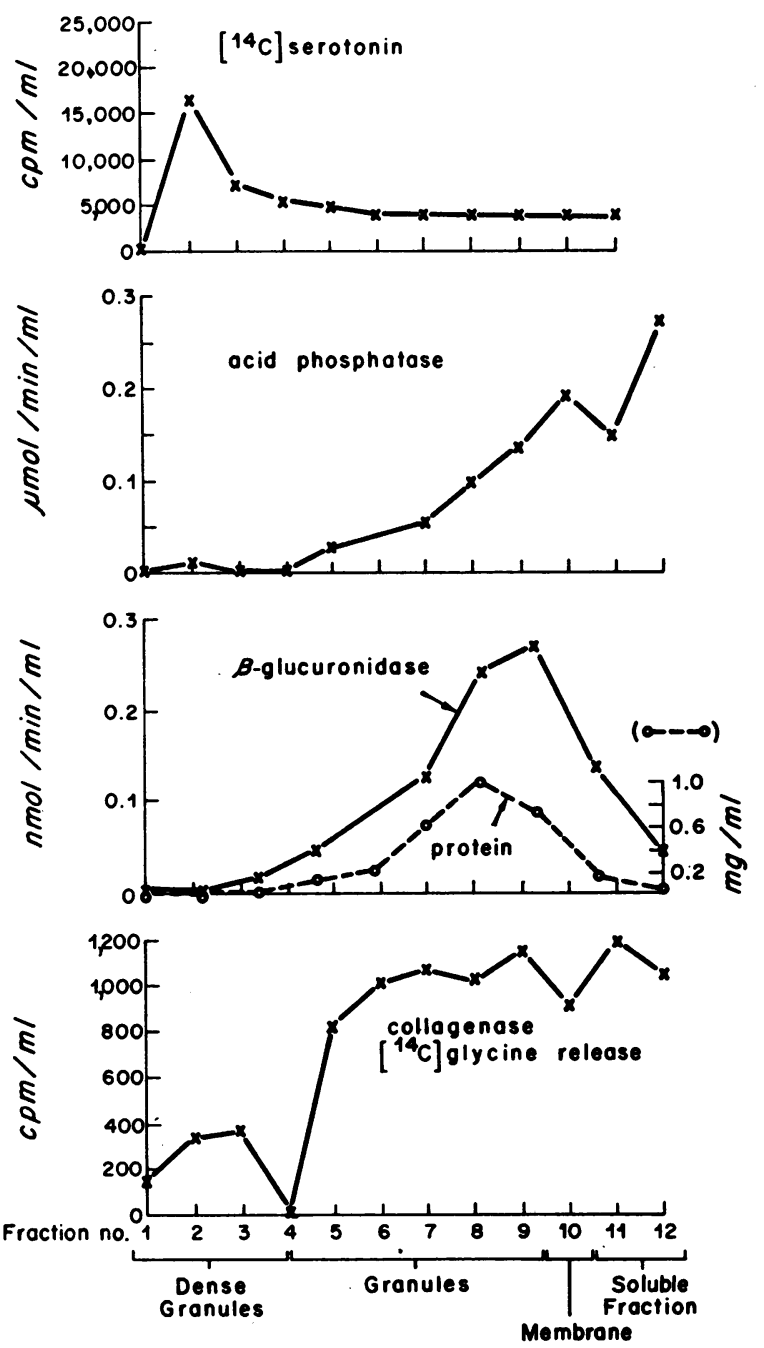

FIGURE 2 (Study A) After ultracentrifugation at 100,000 $g$ for $2 \mathrm{~h}$, the tube was punctured at the bottom with a 20 gauge needle and $0.4-\mathrm{ml}$ fractions were collected.

platelets were first aggregated with the ADP and then EDTA was added to give a final concentration of $3 \mathrm{mM}$; there was no demonstrable collegenase activity.

Acetylsalicylic acid. Incubation of washed platelets with acetylsalicylic acid $(200 \mu \mathrm{M})$ for $15 \mathrm{~min}$ did not inhibit the release of platelet collagenase by $10 \mu \mathrm{M}$ ADP. However, after 30-min incubation no collagenase activity was detectable after exposure to ADP.

Effects of cold on platelet collagenase. Chilling platelets to $4^{\circ} \mathrm{C}$ has been shown to reversibly alter platelet morphology and function. Incubation of platelets at $4^{\circ} \mathrm{C}$ for $30 \mathrm{~min}$ did not result in liberation of collagenase as measured by $\left[{ }^{14} \mathrm{C}\right]$ glycine peptide assay. Rewarming the platelets to $37^{\circ} \mathrm{C}$ for $15 \mathrm{~min}$ after exposure to the cold for $30 \mathrm{~min}$ was not followed by detectable enzyme activity. 


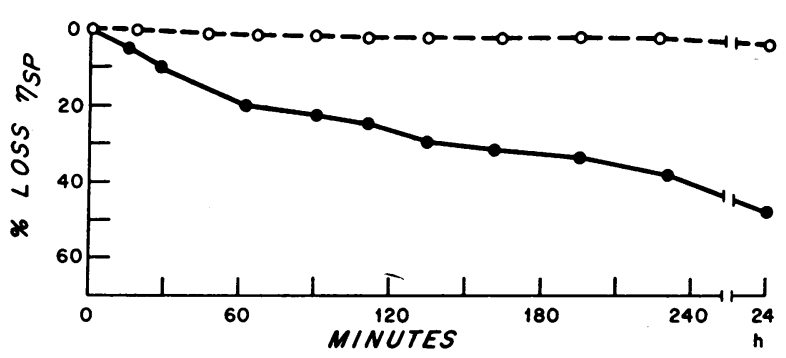

FIGURE 3 Viscometric assay. Human platelet collagenase obtained after aggregation of washed platelets with $10 \mu \mathrm{M}$ ADP was incubated with soluble native guinea pig skin collagen at $27^{\circ} \mathrm{C}$. Aliquots were taken at the times indicated, the viscosity measured, and the specific viscosity calculated.

Demonstration of collagenase by viscometric assay. Collagenase activity was also monitored by viscometric assay (15). Specific viscosity of soluble native guinea pig skin collagen showed a $49 \%$ diminution when incubated at $27^{\circ} \mathrm{C}$ with human platelet collagenase obtained after aggregation of washed platelets with $10 \mu \mathrm{M}$ ADP (Fig. 3).

Demonstration of collagenase activity by analysis of reaction products. Soluble guinea pig skin collagen was incubated with partially purified platelet collagenase at $27^{\circ} \mathrm{C}$ for $18 \mathrm{~h}$. Disk gel electrophoresis of the digestion products are shown in Fig. 4B. The mobility of the reaction products on these gels resembles the $\mathrm{TC}^{\mathbf{A} 2}$ and $\mathrm{TC}^{\mathbf{B} 2}$ fragments obtained from the digestion of collagen with other amphibian and mammalian collagenases.

Digestion of guinea pig skin collagen by human platelet collagenase. Previous studies have shown that collagen digested by collagenase fails to aggregate platelets (7). An equal volume of a partially purified platelet collagenase was incubated with soluble guinea pig skin collagen for $24 \mathrm{~h}$ at $25^{\circ} \mathrm{C}$. The enzyme-digested collagen was incapable of producing platelet aggregation, whereas collagen incubated with buffer retained full activity, as can be seen in Fig. 5 .

\section{DISCUSSION}

Collagenolytic activity has been demonstrated in human platelets by four different methods: release of $\left[{ }^{14} \mathrm{C}\right] \mathrm{gly}-$ cine peptides from collagen, decrease in viscosity of soluble collagen, formation of reaction products characteristic of mammalian collagenase, and loss of the ability of collagen incubated with the enzyme to aggregate platelets. Two other known sources of collagenase, leukocytes and bacteria, have been excluded as contaminants and thus platelets appear to be responsible for the activity observed.

${ }^{2} \mathrm{TC}^{\mathbf{A}}$ is the $\mathrm{N}$-terminal, three-quarter length fragment and $\mathrm{TC}^{\mathrm{B}}$ the C-terminal, one-quarter length fragment resulting from proteolytic digestion of tropocollagen with mammalian or amphibian collagenases.

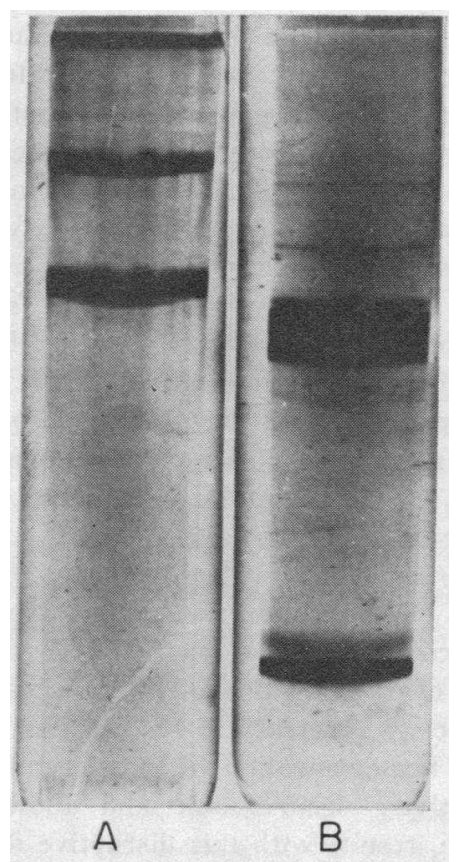

Figure 4 Polyacrylamide disk gel electrophoresis of native guinea pig skin collagen (A) displays the typical forms of collagen. Near the top of the gel is the gamma form of collagen (three chains); the next band is beta (two chains) and the third band is the alpha (single chain). The same collagen after incubation with partially purified human platelet collagenase is shown (B).

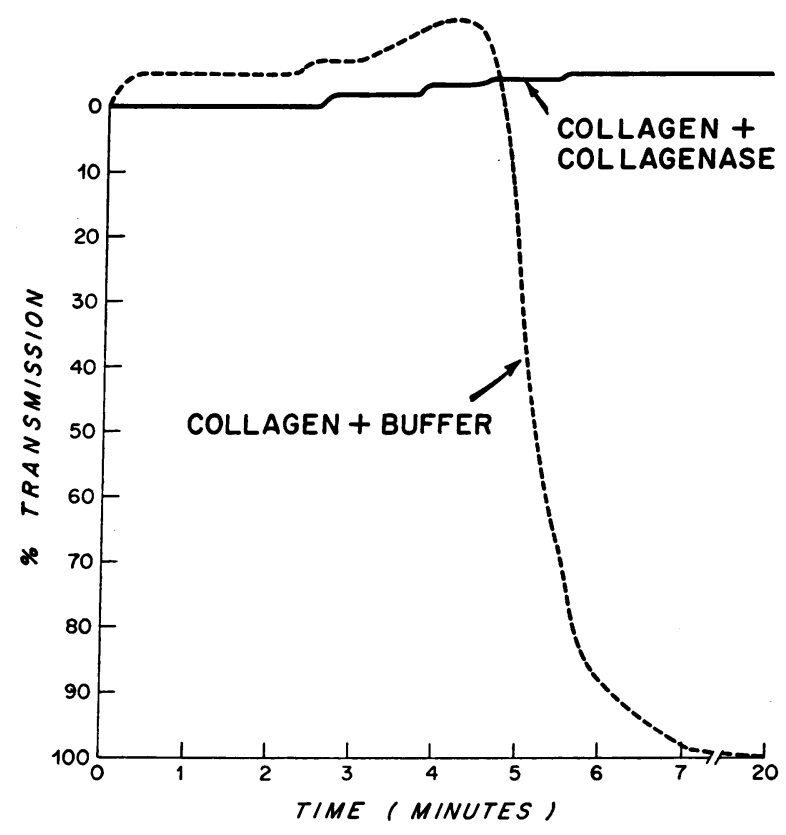

FIGURE 5 Digestion of guinea pig skin collagen by human platelet collagenase. The curves are exact tracings of those recorded. 
Analysis of a platelet homogenate fractionated by means of sucrose density gradients indicates a bimodal distribution of collagenase activity in both membrane and light granule fractions. The identification of the fractions is based not only on the position in the gradient but also on association of appropriate enzyme markers, $5^{\prime}$-nucleotidase for membranes and $\beta$-glucuronidase for granules. In contrast, the location of $\left[{ }^{14} \mathrm{C}\right]$ serotonin differs from that of the collagenase activity. However, the separation by this technique is not perfect and there is some overlap. Therefore, the data may be interpreted with some reservations. This may be the same collagenase in two sites, or two separate collagenases, as has been found in the case of tadpole (21), crab hepatopancreas (22), Clostridium histolyticum (23), Mycobacterium tuberculosis (24), human rheumatoid synovium (25), and rabbit corneal ulcerations (26). Better separation and further characterization of the two platelet collagenase activities is necessary to resolve this question.

Although homogenization of platelets makes the collagenase activity demonstrable and allows subcellular fractionation, results with this disruptive method do not aid in delineating the mode of liberation of the enzyme. Collagenase activity is not apparent in intact, stirred platelets. There are several possible explanations for this finding. The enzyme may exist in an inactive form or may be present in the active form but masked by other constituents. While ADP or collagen liberated collagenase from platelets, no collagenase activity appeared during exposure to the cold or on rewarming, suggesting that shape change itself is not sufficient to demonstrate the enzyme activity. Platelets collected in EDTA and kept at $37^{\circ} \mathrm{C}$ without stirring similarly lose their disk shape but there is no disappearance of the circumferential bands of microtubules (27). No activity was present after exposure to EDTA alone or after addition of ADP to EDTA-anticoagulated platelets. Although one might be tempted to interpret this data to indicate the need for metal-dependent aggregation for release of collagenase, the hypothesis is not yet warranted, because EDTA was found to inhibit platelet collagenase activity as it does other collagenases $(1,2)$ and thus no unique interpretation is possible.

Exposure of platelets to ADP also causes changes in surface contour accompanied by movement of the intracellular organelles toward the center of the platelet. If the concentration of ADP is sufficiently low, the internal reorganization is limited and the process is completely reversible (28). Nevertheless, these changes are correlated with liberation of platelet collagenase. Acetylsalicylic acid, which blocks platelet adhesion to collagen (29) and the release reaction (30), effectively prevents the liberation of collagenase by ADP and epinephrine. Since the release reaction is not necessary for collagenase liberation, it appears that the inhibition by acetylsalicylic acid may be related to the process of adhesion or its immediate sequellae. Although the mechanism of acetylsalicylic acid inhibition may be related to acetylation of a protein (31), presumably in the platelet membrane, or to the inhibition of synthesis of prostaglandin $E_{2}(32)$, the exact action of acetylsalicylic acid on platelets is still unknown.

The experiments on platelets exposed to $4^{\circ} \mathrm{C}$ support the conclusion that a change in shape or disappearance of the circumferential tubules is not itself sufficient to effect the liberation of collagenolytic activity. The platelet release reaction is not necessary, as was shown by the appearance of collagenase activity with a first wave of aggregation and without release of $\left[{ }^{14} \mathrm{C}\right]$ serotonin. Nor is disruption of the lysosomes critical since $\beta$-glucuronidase was not released at a time when platelet collagenase activity was maximal. The actual events leading to the release of platelet collagenase are thus unknown, but the evidence suggests that specific conformational changes in the membrane itself induced by aggregating agents may be responsible. The release of collagenase early in the sequence of events leading to platelet aggregation implies that this enzyme may serve as a useful indication of minimal membrane alteration.

With increasing concentrations of ADP over a 2,000fold range or with collagen, which is a more potent aggregating agents, only about $50 \%$ of the collagenase activity is liberated. Proof of the hypothesis that the liberated collagenase is derived from platelet membranes depends on the isolation of the collagenase released and comparison with the residual collagenase. The possibility that collagenase may exist in a proenzyme form is not ruled out. Existence of procollagenase would require the presence of an activating enzyme, presumably proteolytic in nature, for its conversion to the active species. Zucker (33) has shown that inhibitors of serine proteases interfere with platelet aggregation, suggesting that platelet proteolytic enzymes are involved in the aggregation process. These enzymes may be available for activation of a procollagenase. Evidence for a precursor of collagenase has been found in tadpole (34), mouse bone (35), and leukocytes (36). Therefore, the possibility of the same situation existing in platelets is not remote. Another alternative is that induced conformational change of the procollagenase by substrate may give rise to active enzyme (37).

The repeated finding of significantly less collagenolytic activity in the PRP than in the washed platelet system after exposure to $\mathrm{ADP}$ is due to the presence of plasma inhibitors. Plasma contains $\alpha_{1}$-antitrypsin and $\alpha_{2}$-macroglobulin, which are inhibitors of a number of mammalian collagenases (38). Plasma from a patient with homozygous $\alpha_{1}$-antitrypsin deficiency and $0 \%$ in- 
hibitor (39) produced only partial inhibition, compared to the complete inhibition observed when human platelet collagenase was incubated with normal citrated plasma. This result indicates that $\alpha_{1}$-antitrypsin is one but not the only plasma inhibitor of human platelet collagenase. It is interesting that collagenase activity released by collagen is approximately the same in PRP and in the washed system. This may be due to the fact that substrate collagen protects the enzyme collagenase against inhibitors in the plasma.

Lazarus, Daniels, Lian, and Burleigh (40) have described a collagenase obtained from the granule protein of polymorphonuclear leukocytes which cleaves collagen to form characteristic $\mathrm{TC}^{\mathbf{A}}$ and $\mathrm{TC}^{\mathbf{B}}$ fragments. Since the platelet and granulocyte evolved from a common cell, the amebocyte (41), it was not surprising to find collagenase activity in the platelet granules. Indeed, an increasing number of proteins thought to be characteristic of leukocytes has been demonstrated in platelets, including mediators of vascular permeability (42), bacteriocidal process (43), elastic tissue destruction (3), and chemotaxis (44). This study indicates that collagenase, perhaps derived from the granules of platelets, may be available under certain conditions to play a role in the inflammatory process.

The primary role of platelets, however, is hemostasis. The fact that collagen can liberate an enzyme from platelets which destroys the activity of collagen may constitute a limiting reaction in thrombin formation. The appearance of the collagenase activity early in the hemostatic process may help to assure its apposition to the adherent collagen when vascular injury occurs.

\section{ACKNOWLEDGMENTS}

This work was supported in part by National Institutes of Health grants HL-11519 (R. W. Colman) and AM-15367 (E. Harper).

\section{REFERENCES}

1. Seifter, S., and E. Harper. 1971. The collagenases. In The Enzymes. P. D. Boyer, editor. Academic Press, Inc., New York. 3: 649.

2. Seifter, S., and E. Harper. 1970. Collagenases. In Methods Enzymol. 19: 613.

3. Robert, B., Y. Legrand, G. Pignaud, J. Caen, and L. Robert. 1969. Activité élastinolytique associée aux plaquettes sanguines. Pathol. Biol. 17: 615.

4. Zucker, M., B., and J. Borelli. 1962. Platelet clumping produced by connective tissue suspensions and by collagen. Proc. Soc. Exp. Biol. Med. 109: 779.

5. Wilner, G. D., H. L. Nossel, and E. C. Leroy. 1968. Aggregation of platelets by collagen. J. Clin. Invest. 47: 2616.

6. Tangen, O., H. J. Berman, and P. Marfey. 1971. Gel filtration: a new technique for separation of blood platelets from plasma. Thromb. Diath. Haemorrh. 25: 268.
7. Chesney, C. McI., E. Harper, and R. W. Colman. 1972. Critical role of the carbohydrate side chains of collagen in platelet aggregation. J. Clin. Invest. 51: 2693.

8. Jerushalmy, Z., and M. B. Zucker. 1966. Some effects of fibrinogen degradation products (FDP) on blood platelets. Thromb. Diath. Haemorrh. 15: 413.

9. Fishman, W. H., B. Springer, and R. Burnetti. 1948. Application of an improved glururonidase assay method to the study of human blood $\beta$-glucuronidase. J. Biol. Chem. 173: 449.

10. Brandenberger, H., and R. Hanson. 1953. Spectrophotometric determination of acid and alkaline phosphatases. Helv. Chim. Acta. 36: 900.

11. Dixon, T. F., and M. Purdom. 1954. Serum 5'-nucleotidase. J. Clin. Pathol. (Lond.). 7: 341.

12. Lowry, O. H., N. J. Rosebrough, A. L. Farr, and R. J. Randall. 1951. Protein measurement with the folin phenol reagent. J. Biol. Chem. 193: 265.

13. Gross, J. 1958. Studies on the formation of collagen. I. Properties and fractionation of neutral salt extracts of normal guinea pig connective tissue. J. Exp. Med. 107: 217 .

14. Nagai, Y., J. Gross, and K. A. Piez. 1964. Disc electrophoresis of collagen components. Ann. N. Y. Acad. Sci. $121: 494$.

15. Seifter, S., and P. M. Gallop. 1962. Collagenase from clostridium histolyticum. Methods Enzymol. 5: 659.

16. Nagai, Y., C. M., Lapiere, and J. Gross. 1966. Tadpole collagenase. Preparation and purification. Biochemistry. 5: 3123.

17. Marcus, A. J., D. Zucker-Franklin, L. B. Safier, and H. L. Ullman. 1966. Studies on human platelet granules and membranes. J. Clin. Invest. $45: 14$.

18. De Duve, C. 1963. The lysosome concept. In Lysosomes. A. V. S. de Reuk and M. P. Cameron, editors. Little, Brown and Company, Boston. 1.

19. Harbury, C. B., J. E. Hershgold, and S. S. Schrier. 1972. Requirements for aggregation of washed human platelets suspended in buffered salt solutions. Thromb. Diath. Haemorrh. 28: 2.

20. Michell, R. H., J. L. Harwood, R. Soleman, and J. N. Hawthorne. 1967. Characteristics of rat liver phosphatidylinositol kinase and its presence in the plasma membrane. Biochim. Biophys. Acta. 144: 649.

21. Harper, E., and J. Gross. 1970. Separation of collagenase and peptidase activities of tadpole tissues in culture. Biochim. Biophys. Acta. 198: 286.

22. Eisen, A. Z., K. O. Henderson, J. J. Jeffrey, and R. A. Bradshaw. 1973. A collagenolytic protease from the hepatopancreas of the fiddler crab, UCA pugilator, purification and properties. Biochemistry. 12: 1814.

23. Harper, E., S. Seifter, and V. D. Hospelhorn. 1965. Evidence for subunits in bacterial collagenase. Biochem. Biophys. Res. Commun. 18: 627.

24. Takahashi, S. 1967. Isolation of a collagenolytic enzyme from myobacterium tuberculosis. J. Biochem. (Tokyo). $61: 258$.

25. Harris, E. D., Jr., P. R. DiBona, and S. M. Krane. 1969. Collagenases in human synovial fluid. J. Clin. Invest. $48: 2104$.

26. Brown, S. I., C. A. Weller, and H. E. Wasserman. 1969. Collagenolytic activity of alkalai-burned corneas. Arch. Ophthamol. 81 : 370.

27. White, J. G. 1968. Effects of ethylenediamine tetraacetic acid (EDTA) on platelet structure. Scand. J. Haematol. 5 : 241. 
28. White, J. G., and W. Krivit. 1967. Changes in platelet microtubules and granules during early clot development. In Platelets: Their Role in Hemostasis and Thrombosis. K. M. Brinkhous, editor. Schattauer-Verlag, Stuttgart. 29.

29. Bowie, E. J. W., and C. A. Owen, Jr. 1969. Aspirin, platelets, and bleeding [Editorial]. Circulation. 40: 757.

30. Zucker, M. B., and J. Peterson. 1968. Inhibition of adenosine diphosphate-induced secondary aggregation and other platelet functions by acetylsalicylic acid ingestion. Proc. Soc. Exp. Biol. Med. 127: 547.

31. Al-Mondhiry, H., A. Marcus, and T. H. Spaet. 1969. Acetylation of human platelets by aspirin. Fed. Proc. 28: 576.

32. Kocsis, J. J., J. Hernandovitch, M. J. Silver, J. B. Smith, and C. Ingerman. 1973. Duration of inhibition of platelet prostaglandin formation and aggregation by ingested aspirin or indomethacin. Prostaglandins. 3: 141 .

33. Zucker, M. B. 1972. Proteolytic inhibitors, contact, and other variables in the release reaction of human platelets. Thromb. Diath. Haemorrh. 28: 393.

34. Harper, E., K. J. Bloch, and J. Gross. 1971. The zymogen of tadpole collagenase. Biochemistry. 10: 3035.

35. Vaes, G. 1972. Multiple steps in the activation of the inactive precursor of bone collagenase by trypsin. F.E. B.S. (Fed. Eur. Biochem. Soc.) Lett. 28: 198.
36. Kruze, D., and E. Wojtecka. 1972. Activation of leukocyte collagenase proenzyme by rheumatoid synovial fluid. Biochim. Biophys. Acta. 285 : 436.

37. Kassell, B., and J. Kay. 1973. Zymogens of proteolytic enzymes. Science (Wash. D. C.). 180: 1022.

38. Eisen, A. Z., K. J. Bloch, and. T. Sakai. 1970. Inhibition of human skin collagenase by human serum. $J$. Lab. Clin. Med. 75: 258.

39. Talamo, R. C., G. E. Langley, C. E. Reed, and S. Makino. 1973. $\alpha_{1}$-antitrypsin deficiency: a variant with no detectable $\alpha_{1}$-antitrypsin. Science (Wash. D. C.). $181: 70$.

40. Lazarus, G. S., J. Daniels, J. Lian, and M. C. Burliegh. 1972. Role of granulocyte collagenase in collagen degradation. Am. J. Pathol. 68 : 565.

41. Levin, J. 1967. Blood coagulation and endotoxin in invertebrates. Fed. Proc. 26: 1707

42. Nachman, R. L., B. Weksler, and B. Ferris. 1970. Increased vascular permeability produced by human platelet granule cationic extract. J. Clin. Invest. 49: 274.

43. Weksler, B. B. 1971. Rabbit platelet bacteriocidal protein. J. Exp. Med. $134: 1114$

44. Weksler, B. B., and C. E. Coupal. 1973. Platelet-dependent generation of chemotactic activity in serum. J. Exp. Med. 137 : 1419. 